\title{
MISLOCALIZATION OF CDK11/PITSLRE, A REGULATOR OF THE G2/M PHASE OF THE CELL CYCLE, IN ALZHEIMER DISEASE
}

\author{
VLADAN P. BAJIĆ ${ }^{*}$, BO SU², HYOUNG-GON LEE ${ }^{2}$, WATARU KUDO ${ }^{2}$, \\ SANDRA L. SIEDLAK ${ }^{2}$, LADA ŽIVKOVIĆ ${ }^{3}$, BILJANA SPREMO- \\ POTPAREVIĆ ${ }^{3}$, NINOSLAV DJELIC ${ }^{4}$, ZORANA MILICEVIC ${ }^{5}$, AVNEET K. \\ SINGH $^{2}$, LARA M. FAHMY ${ }^{2}$, XINGLONG WANG ${ }^{2}$, MARK A. SMITH $^{2}$ \\ and XIONGWEI ZHU ${ }^{2} *$ \\ ${ }^{1}$ Institute of Biomedical Research, Galenika a.d., 11000 Belgrade, Serbia, \\ ${ }^{2}$ Department of Pathology, Case Western Reserve University, Cleveland, \\ Ohio 44106 USA, ${ }^{3}$ Institute of Physiology, Department of Biology and Human \\ Genetics, Faculty of Pharmacy, University of Belgrade, 11000 Belgrade, Serbia, \\ ${ }^{4}$ Department of Biology, Faculty of Veterinary Medicine, University \\ of Belgrade, 11000 Belgrade, Serbia, ${ }^{5}$ Institute of Nuclear Sciences "Vinca", \\ Department of Endocrinology and Molecular Biology, Belgrade, Serbia
}

\begin{abstract}
Post-mitotic neurons are typically terminally differentiated and in a quiescent status. However, in Alzheimer disease (AD), many neurons display ectopic re-expression of cell cycle-related proteins. Cyclin-dependent kinase 11 (CDK11) mRNA produces a $110-\mathrm{kDa}$ protein $\left(\mathrm{CDK} 11^{\mathrm{p} 110}\right)$ throughout the cell cycle, a $58-\mathrm{kDa}$ protein $\left(\mathrm{CDK} 11^{\mathrm{p} 58}\right)$ that is specifically translated from an internal ribosome entry site and expressed only in the $G_{2} / M$ phase of the cell cycle, and a $46-\mathrm{kDa}$ protein $\left(\mathrm{CDK} 11^{\mathrm{p} 46}\right)$ that is considered to be apoptosis specific. CDK11 is required for sister chromatid cohesion and the completion of mitosis. In this study, we found that the expression patterns of CDK11 vary such that cytoplasmic CDK11 is increased in AD cellular processes, compared to a pronounced nuclear expression pattern in most controls. We also investigated the effect of amyloid precursor protein (APP) on CDK11 expression in vitro by using M17 cells overexpressing wild-type APP and APP Swedish mutant phenotype and found increased CDK11 expression compared to empty vector. In addition, amyloid- $\beta_{25-35}$ resulted in increased CDK11 in M17 cells. These data suggest that CDK11 may play a vital role in cell cycle re-entry in AD neurons in
\end{abstract}

* Authors for correspondence. e-mails: vladanbajic@yahoo.com and xiongwei.zhu@case.edu

Abbreviations used: A $\beta$ - amyloid- $\beta$; AD - Alzheimer disease; APP - amyloid precursor protein; CDK11 - cyclin-dependent kinase 11; CDKIs - cyclin-dependent kinase inhibitors; IRES - internal ribosome entry site; MT -microtubule 
an APP-dependent manner, thus presenting an intriguing novel function of the APP signaling pathway in AD.

Key words: Alzheimer disease, APP, CDK11, M17 cells

\section{INTRODUCTION}

Neuronal cell death is the main characteristic of Alzheimer disease (AD), causing clinical symptoms of senile dementia among older people manifested by a progressive loss of memory and other intellectual functions. The primary causes of cell death are unclear. It is known that genetic and environmental factors play an important role in AD etiology $[1,2]$.

For some time there has been a notion that altered cell cycle events in vulnerable neurons precede the occurrence of amyloid- $\beta(\mathrm{A} \beta)$ deposits and neurofibrillary tangles, the hallmarks of $\mathrm{AD}$ [3-6], and lead to degeneration of select neuronal populations in the hippocampus and other cortical brain regions. Ectopic expression of a number of mitosis-specific proteins has been reported in susceptible neurons in AD [7-12]. Recently it was found that amyloid precursor protein (APP) signaling processing, which results in the formation of $A \beta$ in an oligomeric form, can drive neuronal cells into a new cell cycle, opening the door to neurodegeneration and consequently cell death [13-15].

In mammalian cells, re-entry into the cell division cycle depends on extracellular signals, namely on the balance between mitogenic stimuli and differentiating factors [9, 16, 17]. Sequential expression, activation, and degradation of cyclin/cyclin-dependent kinase complexes drive the cell cycle, while their regulation is achieved via mechanisms of transcription, phosphorylation, proteolysis, and association with cyclin-dependent kinase inhibitors (CDKIs) [18]. $\mathrm{G}_{0} / \mathrm{G}_{1}$ phase transfer in the cell cycle is triggered by the presence of cyclin $\mathrm{D} / \mathrm{cdk} 4$ and cdk6 complex [19]. When DNA replication is complete, the cyclin A/cdk2 complex enables transition from the $S$ to the $G_{2}$ phase $\left(S / G_{2}\right)$ of the cell cycle. For the cell to enter the $G_{2}$ phase of mitosis $\left(G_{2} / M\right)$, degradation of cyclin $\mathrm{A} / \mathrm{cdk} 2$ complex and expression of cyclin $\mathrm{B}$, which activates cdk2, must take place [19].

CDK11 regulates the $\mathrm{G}_{2} / \mathrm{M}$ phase of the cell cycle by interacting with cyclin D3 [20]. In humans CDK11 is encoded by two highly homologous genes named Cdc2L1 and Cdc2L2 (cell division control 2 like). CDK11 is also known as PITSLRE for a conserved motif in its kinase domain and involves major isoforms from a number of splice variants. At least 10 CDK11 isoforms have been cloned in eukaryotic cells, with molecular weight varying from 46 to $110 \mathrm{kDa}$ [21]. Major isoforms are CDK11 $1^{\mathrm{p} 110}, \mathrm{CDK}_{1} 1^{\mathrm{p} 58}[22,23]$, and CDK11 ${ }^{\mathrm{p} 46}$ [24]. The larger CDK $11^{\mathrm{p} 110}$ is a 779 -amino-acid-containing protein, representing the whole gene, and is ubiquitously expressed in all cell lines and constantly through the cell cycle [22]. CDK11 $11^{\mathrm{p} 110}$ localizes to both splicing factor compartments (SFC-s) and to the nucleoplasm [25]. Another function recently 
reported is that CDK $11^{\text {p110 }}$ is a Ran GTP-dependent microtubule (MT) stabilization factor that has an essential role in spindle assembly formation [26].

The smaller CDK $11^{\mathrm{p} 58}$ isoform is cell cycle regulated, and its synthesis occurs through the internal ribosome entry site (IRES), which is used only in the $\mathrm{G}_{2} / \mathrm{M}$ transition [27]. Although CDK $11^{\mathrm{p} 58}$ and $\mathrm{CDK} 11^{\mathrm{p} 110}$ share many of the same sequences, including the kinase domain, the two isoforms are involved in different regulatory pathways in eukaryotic cells. CDK $11^{\mathrm{p} 58}$ is closely associated with cell cycle arrest and apoptosis in a kinase-dependent manner by caspase cleavage, producing an apoptotic kinase regulator, CDK11 ${ }^{\mathrm{p} 46}[28-30]$. Recent studies also revealed that CDK11 is implicated in differentiation, neuronal physiology, androgen receptor attenuation [31], centrosome maturation, bipolar spindle formation, centromere cohesion [32], and tumorigenesis [29, 33, 34].

The recent findings that the chromatid cohesion protein regulator cohesin is expressed in differentiated postmitotic neurons [35] and that premature centromere division phenotype is a feature of $\mathrm{AD}$ [36-39] led us to evaluate CDK11 isoform expression levels in vivo in AD brain compared to age-matched controls. Further in vitro studies found increased expression levels of CDK11 in M17 cells overexpressing wild and mutant (Swedish mutation) APP phenotypes.

\section{MATERIALS AND METHODS}

\section{Tissue}

Hippocampal tissue was collected at Case Western Reserve University and the University Hospitals of Cleveland at autopsy following IRB-approved protocols. Cases of $\mathrm{AD}$ were evaluated by a neuropathologist, met CERAD criteria, and underwent Braak staging. Control cases were also assigned by CERAD criteria and, in some cases, showed only age-related pathological structures identified with phosphorylated tau (AT8), and all controls were also negative for other neurological pathologies. Hippocampal tissue from cases of $\mathrm{AD}(n=23$, ages 59-91 years), young controls ( $\mathrm{n}=4$, ages 20-45 years), and aged-matched controls ( $n=11$, ages 53-86 years) with similar postmortem intervals (AD, 2.5-23 h; controls, 3.5-42 h) were fixed in methacarn (methanol: chloroform: acetic acid; 60:30:10) or routine formalin at $4^{\circ} \mathrm{C}$ overnight. Following fixation, tissue was dehydrated through ascending ethanol, embedded in paraffin, and sectioned at $6 \mu \mathrm{m}$.

\section{Immunocytochemistry}

Tissue sections were deparaffinized in xylene, and hydrated through descending ethanol to Tris buffer $(50 \mathrm{mM}$ Tris, $150 \mathrm{mM} \mathrm{NaCl}, \mathrm{pH}=7.6)$. Endogenous peroxidase activity was abolished with a 30 -min incubation in $3 \% \mathrm{H}_{2} \mathrm{O}_{2}$ in methanol. Non-specific binding sites were blocked with a 30 -min incubation in $10 \%$ normal goat serum. Tissue sections were immunostained with two different rabbit antisera to CDK11 directed against the C-terminus (epitope 730-780) (Novus biological and Abcam) followed by the peroxidase-antiperoxidase method with 3,3'-diaminobenzidine as co-substrate as previously described [40]. 
This epitope is also found on the related protein Cdc1L1. Some sections underwent pressure cooking using a $0.01 \mathrm{M}$ anhydrous citrate buffer brought to maximum pressure for $10 \mathrm{~min}$ followed by a 10 -min distilled water bath. Some sections were counterstained with Congo red to assess co-localization of staining with pathological structures. Also, adjacent sections were immunostained with antiserum to phosphorylated tau (AT8, Endogen) to identify the location of pathological structures. Control experiments included omission of primary antisera. Double staining experiments were performed to compare the staining patterns of CDK11 and glial fibrillary acidic protein (GFAP), which detects astroglial cells. A mouse monoclonal antibody to GFAP was used and detected using the alkaline phosphatase anti-alkaline phosphatase method with Fast Blue as chromogen.

Using a Zeiss Axiocam and image analysis software, 3 fields of the CA1 and $\mathrm{CA} 2$ region of the hippocampus from 4 cases of $\mathrm{AD}$ and 4 control cases were imaged, and the percent area stained for CDK11 in the neuronal cell bodies and cellular processes determined. Student's t-test was used to compare the AD and control cases.

\section{Western blot}

M17 cells were grown overexpressing wild type (APPwt) or Swedish APP (APPswe), or with vector only according to previously published methods [41]. For some experiments cells were harvested for Western blot analysis and homogenized with lysis buffer [50 mM Tris- $\mathrm{HCl}(\mathrm{pH} 7.6)$ containing $0.02 \%$ sodium azide, $0.5 \%$ sodium deoxycholate, $0.1 \%$ SDS, $1 \%$ NP- $40,150 \mathrm{mM}$ $\mathrm{NaCl}, 1 \mathrm{mM}$ phenylmethylsulfonyl fluoride, protease inhibitors cocktail from Roche], and centrifuged at $16000 \mathrm{xg}$ for $10 \mathrm{~min}$ at $4^{\circ} \mathrm{C}$.

Frozen brain tissue from $\mathrm{AD}$ cases $(\mathrm{n}=12)$ and age-matched control cases $(\mathrm{n}=12)$ was homogenized in lysis buffer with protease inhibitors and centrifuged at $16000 \mathrm{x} \mathrm{g}$ for $10 \mathrm{~min}$ at $4^{\circ} \mathrm{C}$. The protein concentration of the cellular and brain supernatants was determined using the bicinchoninic acid assay method (Pierce, Rockford, IL, USA). Equal amounts of protein were loaded per lane and proteins were separated by SDS-PAGE and electroblotted onto Immobilon-P (Millipore, Bedford, MA, USA) by standard procedures as described before [42]. Antibodies used for Western blot were CDK11 (Abcam, Cambridge, MA, USA), 1:1000, CDK11 (Novus Biologicals, Littleton, CO, USA), 1:1000 and mouse anti- $\beta$-actin (Chemicon, Temecula, CA, USA) 1:10 000. The same membranes were stripped and probed for $\beta$-actin as an internal loading control. Quantification of the blots was performed using a computer-assisted scanning system (Quantity One 4.3, Bio-Rad, USA). Results are reported as mean values \pm SEM. Significant differences between different groups were assessed by twotailed Student's t-test with $\mathrm{p}<0.05$ considered statistically significant.

\section{Immunocytochemistry of APP-overexpressing cells}

Cells grown on chamber slides were fixed with paraformaldehyde, then permeabilized with $0.2 \%$ Triton $\mathrm{X}-100$ and blocked with $10 \%$ normal goat 
serum in PBS overnight at $4^{\circ} \mathrm{C}$. After blocking, cells were incubated with antibody against CDK11 for $1 \mathrm{~h}$ at room temperature, incubated with secondary antibody conjugated to Alexa Fluor 488 for $30 \mathrm{~min}$ at room temperature. Slides were mounted with medium containing DAPI to visualize nuclei and imaged using fluorescent microscopy.

\section{Cell culture treatment with $\mathbf{A} \boldsymbol{\beta}_{25-35}$}

Immunofluorescence was performed as described [43]. Briefly M17 cells were cultured on chamber slides. After $A \beta_{25-35}(40 \mu \mathrm{M})$ treatment for $6 \mathrm{~h}$, cells were washed twice with PBS and then fixed with $4 \%$ paraformaldehyde for $45 \mathrm{~min}$ at room temperature. Cells were permeabilized with $0.5 \%$ Triton X-100 for $30 \mathrm{~min}$, blocked with $10 \%$ normal goat serum for $30 \mathrm{~min}$, and incubated with primary antibodies in PBS overnight at $4^{\circ} \mathrm{C}$. After three washes with PBS, cells were incubated with Alexa Fluor 488-conjugated secondary antibody (Invitrogen, Carlsbad, CA, USA) $(1: 300)$ for $1 \mathrm{~h}$ at $37^{\circ} \mathrm{C}$ in the dark. Cells were rinsed three times with PBS and mounted with anti-fade medium containing DAPI (Southern Biotech, Birmingham, AL). All fluorescence images were captured with a Zeiss LSM 510 inverted fluorescence microscope (Zeiss, Oberkochen, Germany).

\section{RESULTS}

Immunohistochemical studies revealed different patterns of CDK11 immunoreactivity in the hippocampus of $\mathrm{AD}$ cases compared to the age-matched controls. The majority of control cases as well as $\mathrm{AD}$ cases exhibited some cytoplasmic CDK11 immunoreactivity within pyramidal neurons of the hippocampus. However, significant CDK11 nuclear localization was a feature of 11 out of the 15 controls (Fig. 1A,B) and only 1 AD case. Notably, only in the AD group were cellular processes a specific site of CDK11 accumulation (Fig. 1C,D), and this was seen in the majority of AD cases. Double-label immunocytochemistry with GFAP, a marker of astrocytes, revealed that the majority of cellular processes were not GFAP-positive, and likely were neuronal (Fig. 1F). There were 4 control and 5 AD cases that showed very little cytoplasmic or nuclear CDK11, and these cases had no distinguishing characteristics or correlated to age or disease severity.

Quantification of representative AD and control cases found that an average of over $80 \%$ of the CDK11 staining in the hippocampus was localized to cellular processes in the $\mathrm{AD}$ cases. In the control cases, however, over $50 \%$ of the staining was found localized in the nuclei and soma. These differences were found to be statistically significant (Fig. 1E, p < 0.001). CDK11 was not specifically found in the pathological lesions of $\mathrm{AD}$ when compared with Congo red or tau immunohistochemistry (data not shown). 

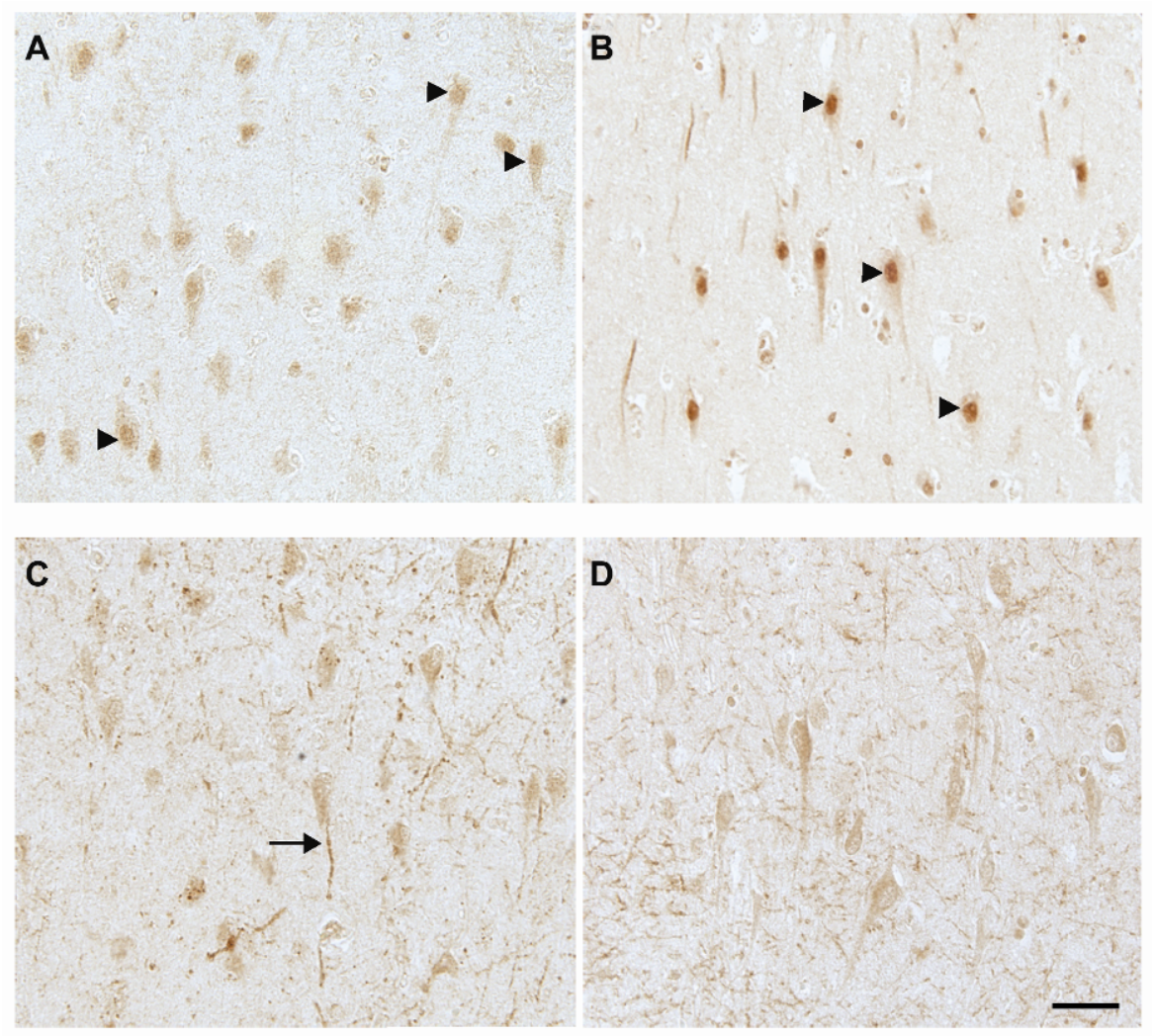

\section{E}
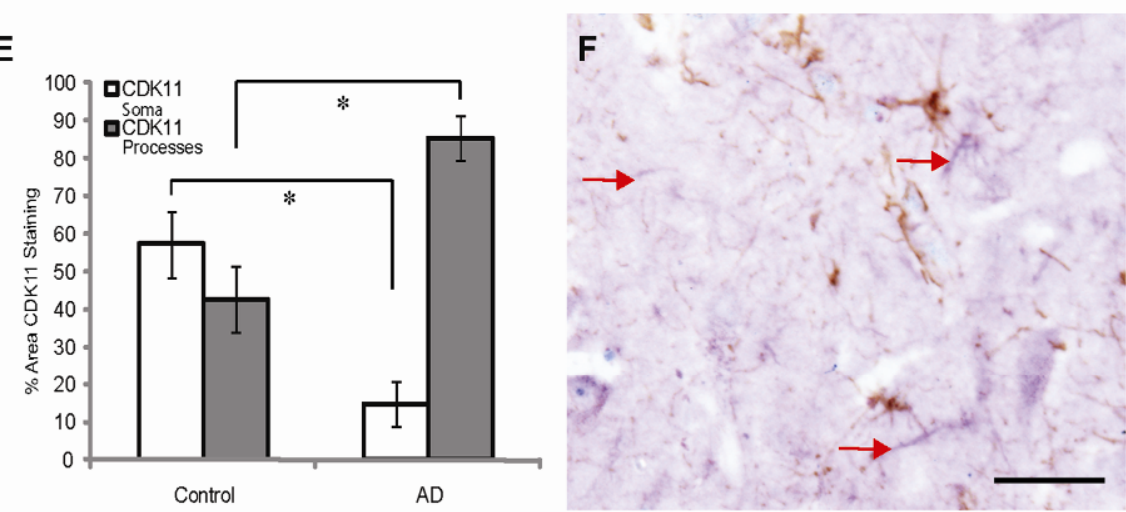

Fig. 1. Localization of CDK11 in hippocampal neurons from 2 representative control cases displaying weak cytoplasm and significant nuclear localization, arrowheads (A, B). CDK11, in 2 representative cases of $\mathrm{AD}$, was localized to the neuronal cytoplasm and processes (arrow) throughout the hippocampus (C, D). Double label immunocytochemistry with GFAP (F, brown) revealed that the majority of CDK11 processes (F, blue stain, red arrows) are not glial and likely derive from neurons. Nuclei were not specifically labeled in nearly all the AD cases. Quantification revealed striking differences of CDK11 staining of the soma and cellular processes between $\operatorname{AD}(n=4)$ and control $(n=4)$ cases. $(E, * p<0.01)$. Scale bars $=50 \mu \mathrm{m}$. 


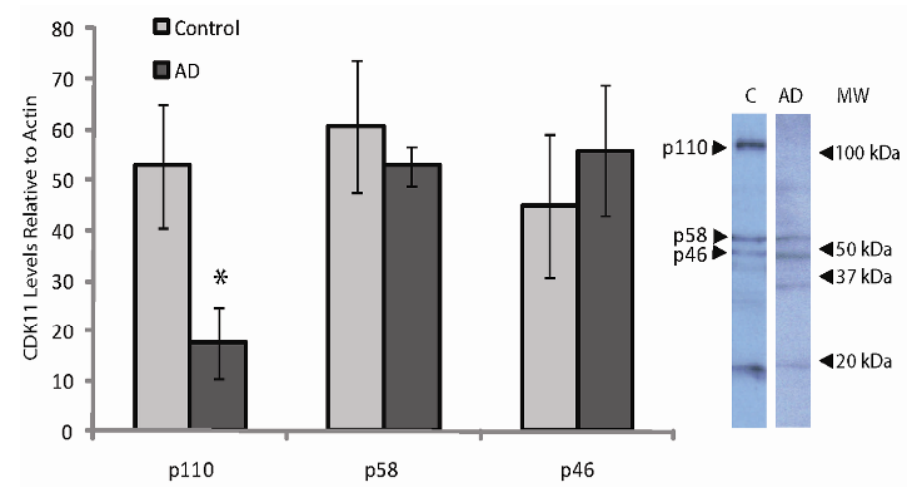

Fig. 2. Western blot analysis of frozen brain tissue revealed that only the CDK $11^{\mathrm{p} 110}$ isoform is present at higher levels in the control cases compared to AD cases $(* p<0.05)$. Data are expressed as mean \pm SEM of CDK $11^{\mathrm{p} 110}, \mathrm{CDK} 11^{\mathrm{p} 58}$, and CDK $11^{\mathrm{p} 46}$ protein levels relative to actin from $\operatorname{AD}$ cases $(n=12)$ and age-matched controls $(n=12)$. Representative lanes showing the specific detection of CDK11 are shown.

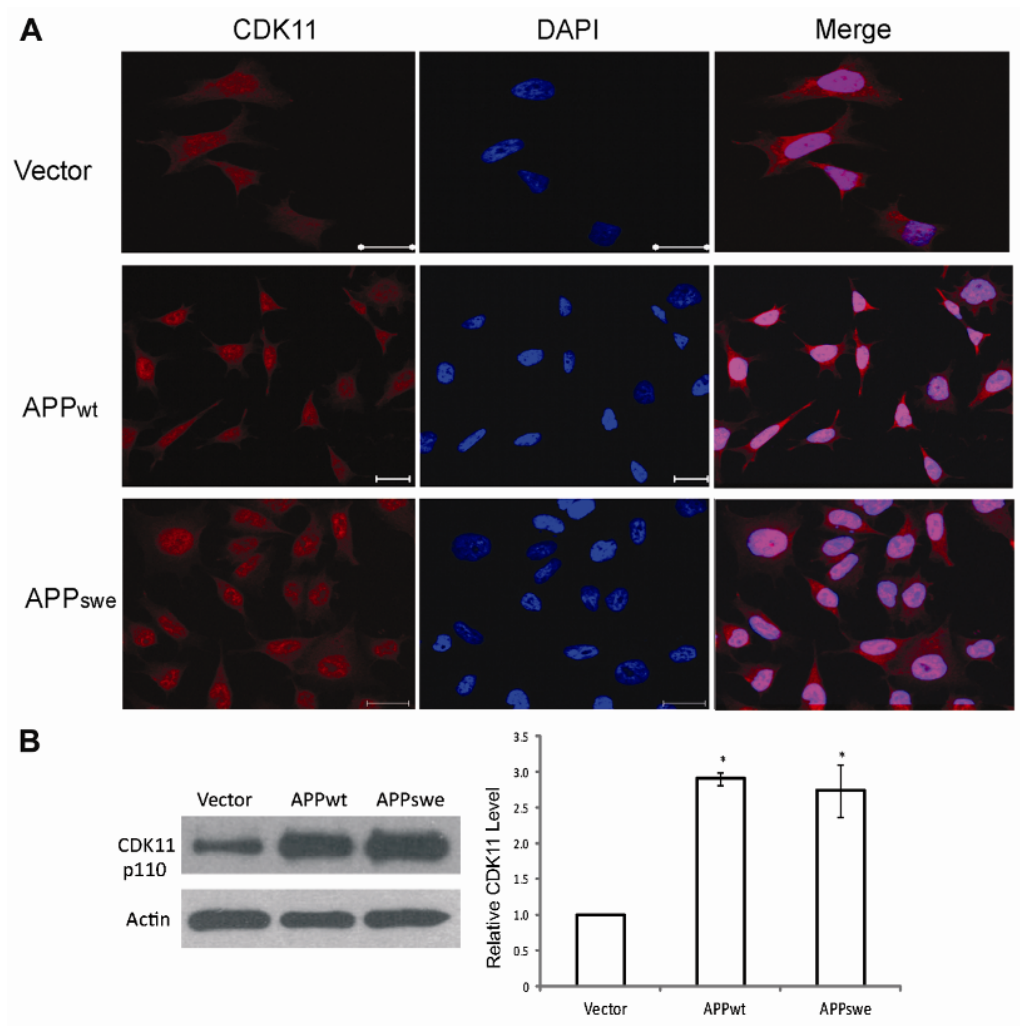

Fig. 3. Representative images of CDK11 in M17 cells with empty vector or APPwt or APPswe overexpression (A). CDK11 expression levels were examined by Western blot (B). Quantification found significantly higher levels of CDK11 in cells overexpressing APP (mean $\pm \mathrm{SEM}) . *$ indicates significant difference between vector control and APPwt or APPswe cells with $\mathrm{p}<0.05$. Scale bars $=50 \mu \mathrm{m}$. 
Western blot analysis of human brain samples revealed that the antibodies detected specific bands corresponding to CDK $11^{\mathrm{p} 110}, \mathrm{CDK} 11^{\mathrm{p} 58}$, and CDK $11^{\mathrm{p} 46}$. Quantification found that CDK11 $1^{\mathrm{p} 110}$ is present at higher levels in the control cases $(p<0.05)$, and representative lanes of the AD and control samples are shown (Fig. 2).

CDK11 expression levels in M17 cells with empty vector or APPwt or mutant APP overexpression were examined using fluorescent microscopy. Both the APPwt and APPswe overexpressing cells displayed greater CDK11 immunoreactivity than the cells with vector alone (Fig. 3A). While the strongest labeling was apparent in the nuclei, when compared to the DAPI localization, some CDK11 was also demonstrated in the cytoplasm. Western blot analysis of the cell lysates revealed the CDK $11^{\mathrm{p} 110}$ isoform to be the dominant form. Quantification of the CDK11 levels revealed that both the APPwt and APPswe cells expressed significantly higher levels of CDK11.

M17 cells were then treated with $A \beta_{25-35}$ peptide for $6 \mathrm{~h}$, a treatment time that did not cause significant cell death. Compared with untreated cells, CDK11 localization was greatly increased throughout the cells following exposure to $A \beta$ (Fig. 4).
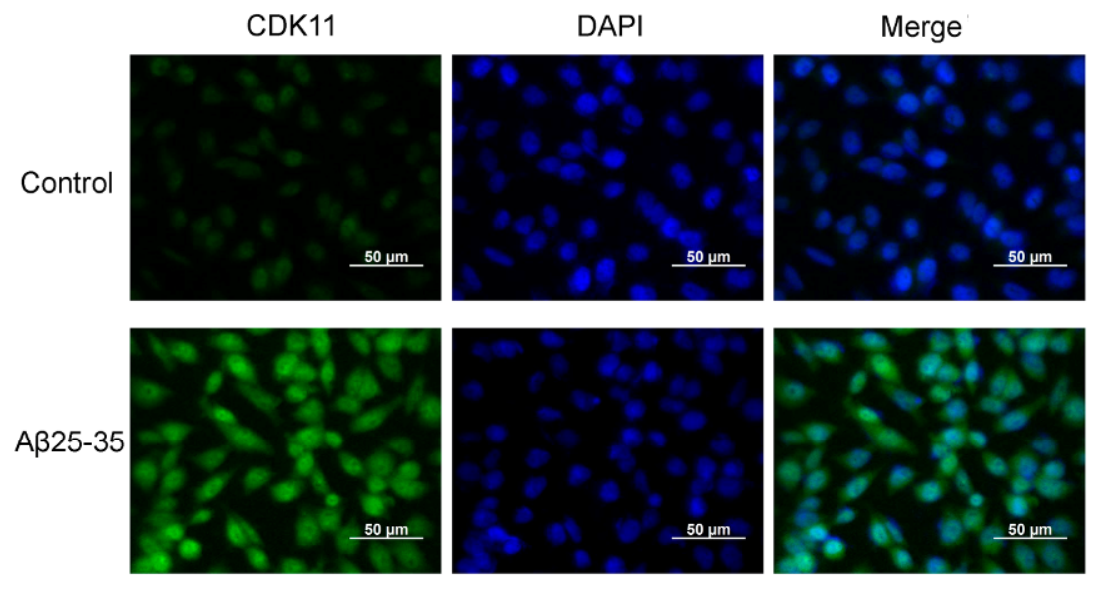

Fig. 4. Localization of CDK11 in M17 cells treated with $A \beta_{25-35}$. Compared to untreated cells, the immunohistochemistry data show that $A \beta_{25-35}(40 \mu \mathrm{M})$ treatment for $6 \mathrm{~h}$ induces upregulation of CDK11 in the neuronal cytoplasm.

\section{DISCUSSION}

In this study, we demonstrated that $\mathrm{CDK} 11, \mathrm{a} \mathrm{G}_{2} / \mathrm{M}$ phase regulator of the cell cycle, is found in the cytoplasm and cellular processes of the pyramidal neurons and other cells in many cases of AD, yet in most control samples CDK11 is expressed at much higher levels in the nuclei. Western blot analysis confirms differences in CDK $11^{\mathrm{p} 110}$ levels between $\mathrm{AD}$ and control groups, which may reflect the increased nuclear localization found in the normal human 
hippocampal tissue sections. Together these data suggest mislocalization of CDK11 from the nuclei to the cytoplasm and processes in AD. The same distribution of ectopic re-expression in the AD brain (cytoplasm versus neuronal nuclei) has been reported for a number of cell cycle regulators such as Polo-like kinases, neuronal CIP-1-associated regulator of cyclin B (CARB), and p130, a retinoblastoma-related protein [44-46], as well as mitogenic signal transduction pathway components [47-49].

It is still under debate whether susceptible neurons arrest at some point between the $G_{1}$ and $M$ phases of the cell cycle. A number of studies have found concordance of elevated levels of cyclin/CDK levels, cyclins that control the $\mathrm{G}_{2} / \mathrm{M}$ transition and chromosomal instability in neuronal cells $[5,50]$. Chromosomal instability phenotypes such as tetraploidy [51], binuclear neuronal cells [52], and premature centromere separation [53], which correlate to the $\mathrm{G}_{2} / \mathrm{M}$ phase of the cell cycle, have also been found to be increased in AD.

The findings presented here represent a multi-faceted CDK11 function in AD. In vitro analysis of the effect of APP, by using cells that overexpress APPwt and APPswe, finds that CDK11 is increased compared to cells with vector only. Further, in M17 cells, treatment with $\mathrm{A} \beta$ peptide also results in increased CDK11. Yet, in cells with either APP overexpression or its AD-associated cleavage products, only CDK $11^{\mathrm{p} 110}$ isoform was detected. APPwt and APPswe overexpression represents both sporadic and genetically linked AD. CDK11 dysfunction may be vital to understanding the neuronal degeneration due to the fact that it is similar in the model representing sporadic disease, as this accounts for over $90 \%$ of cases of $\mathrm{AD}$. In human disease tissue collected at the time of autopsy, which is often decades after disease onset, the mislocalization of CDK11 from the nucleus to the cytoplasm and peripheral cellular processes, a morphological feature not found in normal brain, suggests an abnormal cellular response to cellular stress via CDK11. The significant loss of CDK11 $11^{\mathrm{p} 110}$ in the human brain samples of $\mathrm{AD}$ points to this mislocalization seen by morphological analysis. The cleavage of $\mathrm{CDK} 11^{\mathrm{p} 110}$ to $\mathrm{CDK} 11^{\mathrm{p} 58}$ and $\mathrm{CDK} 11^{\mathrm{p} 46}$ can represent cell cycle re-entry and arrest as well as apoptotic pathways. The dysfunctional interplay of CDK11, and perhaps other CDK proteins that share homology with CDK11, with APP in AD and AD models points to the emerging roles of synaptic abnormalities, cell cycle re-entry, and microtubule impairment and transport, and it is the disruption of these associated cellular mechanisms that underlies the loss of neuronal connectivity and provides the basis of cognitive loss in AD [54].

It is evident that in AD there is aberrant localization of nuclear proteins involved in cell cycle activation, including various cyclins. The inappropriate localization of nuclear proteins to the cytoplasm of neurons in AD may lead us to suspect a dysfunction in the nucleoplasmic transport mechanism of proteins, importins, and congruently the engine that enables proteins to be imported in and out of the nuclei, the GTPase RAN. RAN-GTP controls both MT micronucleation and plus end stabilization. In hippocampal neurons from $\mathrm{AD}$ patients importin $\alpha$ is 
abnormally expressed [55], indicating impairment of microtubular transport. CDK11 localizes to spindle microtubules (MT) and centrosomes, and may bind to MT through an interaction with its substrate. In the absence of CDK11, MT are shorter, whereas spindle assembly takes a longer time to organize [26]. Given the notion that under normal function conditions CDK11 needs to be present in the nucleus of neuronal cells [20], both the loss of nuclear localization in $\mathrm{AD}$ brain sections and the increase in the cellular processes may correlate to failed attempts of these neurons to maintain a differentiated or quiescent state. This reinforces an old question raised in studies of mislocalization of many cell cycle markers and signal transduction molecules: why do these nuclear proteins accumulate in the cytoplasm in disease states? Is it an active or passive process? Is it a problem of nuclear-cytoplasm transport or a problem of decreased proteolytic activity of neurons during AD?

In conclusion, alteration of CDK11 localization in specific cellular populations as well as in $\mathrm{AD}$, and $\mathrm{APP}$ and $\mathrm{A} \beta$-induced $\mathrm{CDK} 11^{\mathrm{p} 110}$ expression in cell culture models, suggest key alterations in neuronal homeostasis in the disease. Further work will delineate the APP-CDK11 connection and its significance for the APP signaling pathway in the course of the disease.

Acknowledgements. Work in the authors' laboratories is supported by the Serbian Ministry of Science (grant \#173034) and by the National Institutes of Health (AG028679 and AG031364).

\section{REFERENCES}

1. Rosenberg, R.N. The molecular and genetic basis of AD: the end of the beginning: the 2000 Wartenberg lecture. Neurology 54 (2000) 2045-2054.

2. Steele, C.D. The genetics of Alzheimer disease. Nurs. Clin. North Am. $\underline{35}$ (2000) 687-694.

3. Smith, M.A. Alzheimer disease. Int. Rev. Neurobiol. 42 (1998) 1-54.

4. Vincent, I., Rosado, M. and Davies, P. Mitotic mechanisms in Alzheimer's disease? J. Cell Biol. 132 (1996) 413-425.

5. Vincent, I., Jicha, G., Rosado, M. and Dickson, D.W. Aberrant expression of mitotic cdc2/cyclin B1 kinase in degenerating neurons of Alzheimer's disease brain. J. Neurosci. 17 (1997) 3588-3598.

6. McShea, A., Wahl, A.F. and Smith, M.A. Re-entry into the cell cycle: a mechanism for neurodegeneration in Alzheimer disease. Med. Hypotheses 52 (1999) 525-527.

7. Arendt, T., Rodel, L., Gartner, U. and Holzer, M. Expression of the cyclindependent kinase inhibitor p16 in Alzheimer's disease. Neuroreport $\underline{7}$ (1996) 3047-3049.

8. McShea, A., Harris, P.L., Webster, K.R., Wahl, A.F. and Smith, M.A. Abnormal expression of the cell cycle regulators P16 and CDK4 in Alzheimer's disease. Am. J. Pathol. 150 (1997) 1933-1939. 
9. Raina, A.K., Zhu, X. and Smith, M.A. Alzheimer's disease and the cell cycle. Acta Neurobiol. Exp. (Wars) 64 (2004) 107-112.

10. Zhu, X., Raina, A.K., Boux, H., Simmons, Z.L., Takeda, A. and Smith, M.A. Activation of oncogenic pathways in degenerating neurons in Alzheimer disease. Int. J. Dev. Neurosci. 18 (2000) 433-437.

11. Nagy, Z., Esiri, M.M., Hindley, N.J., Joachim, C., Morris, J.H., King, E.M., McDonald, B., Litchfield, S., Barnetson, L., Jobst, K.A. and Smith, A.D. Accuracy of clinical operational diagnostic criteria for Alzheimer's disease in relation to different pathological diagnostic protocols. Dement. Geriatr. Cogn. Disord. 9 (1998) 219-226.

12. Lee, H.G., Casadesus, G., Zhu, X., Castellani, R.J., McShea, A., Perry, G., Petersen, R.B., Bajic, V. and Smith, M.A. Cell cycle re-entry mediated neurodegeneration and its treatment role in the pathogenesis of Alzheimer's disease. Neurochem. Int. 54 (2009) 84-88.

13. Varvel, N.H., Bhaskar, K., Patil, A.R., Pimplikar, S.W., Herrup, K. and Lamb, B.T. Abeta oligomers induce neuronal cell cycle events in Alzheimer's disease. J. Neurosci. 28 (2008) 10786-10793.

14. Tomiyama, T., Matsuyama, S., Iso, H., Umeda, T., Takuma, H., Ohnishi, K., Ishibashi, K., Teraoka, R., Sakama, N., Yamashita, T., Nishitsuji, K., Ito, K., Shimada, H., Lambert, M.P., Klein, W.L. and Mori, H. A mouse model of amyloid beta oligomers: their contribution to synaptic alteration, abnormal tau phosphorylation, glial activation, and neuronal loss in vivo. J. Neurosci. $\underline{30}$ (2010) 4845-4856.

15. Tomiyama, T., Nagata, T., Shimada, H., Teraoka, R., Fukushima, A., Kanemitsu, H., Takuma, H., Kuwano, R., Imagawa, M., Ataka, S., Wada, Y., Yoshioka, E., Nishizaki, T., Watanabe, Y. and Mori, H. A new amyloid beta variant favoring oligomerization in Alzheimer's-type dementia. Ann. Neurol. 63 (2008) 377-387.

16. Lavoie, J.N., Rivard, N., L'Allemain, G. and Pouyssegur, J. A temporal and biochemical link between growth factor-activated MAP kinases, cyclin D1 induction and cell cycle entry. Prog. Cell Cycle Res. 2 (1996) 49-58.

17. Reed, S.I. G1/S regulatory mechanisms from yeast to man. Prog. Cell Cycle Res. $\underline{2}$ (1996) 15-27.

18. Grana, X. and Reddy, E.P. Cell cycle control in mammalian cells: role of cyclins, cyclin dependent kinases (CDKs), growth suppressor genes and cyclin-dependent kinase inhibitors (CKIs). Oncogene 11 (1995) 211-219.

19. McDonald, D.R., Bamberger, M.E., Combs, C.K. and Landreth, G.E. betaAmyloid fibrils activate parallel mitogen-activated protein kinase pathways in microglia and THP1 monocytes. J. Neurosci. 18 (1998) 4451-4460.

20. Zhang, S., Cai, M., Zhang, S., Xu, S., Chen, S., Chen, X., Chen, C. and Gu, J. Interaction of p58(PITSLRE), a G2/M-specific protein kinase, with cyclin D3. J. Biol. Chem. 277 (2002) 35314-35322.

21. Li, Z., Wang, H., Zong, H., Sun, Q., Kong, X., Jiang, J. and Gu, J. Downregulation of beta1,4-galactosyltransferase 1 inhibits CDK11(p58)- 
mediated apoptosis induced by cycloheximide. Biochem. Biophys. Res. Commun. 327 (2005) 628-636.

22. Xiang, J., Lahti, J.M., Grenet, J., Easton, J. and Kidd, V.J. Molecular cloning and expression of alternatively spliced PITSLRE protein kinase isoforms. J. Biol. Chem. 269 (1994) 15786-15794.

23. Gururajan, R., Lahti, J.M., Grenet, J., Easton, J., Gruber, I., Ambros, P.F. and Kidd, V.J. Duplication of a genomic region containing the Cdc2L1-2 and MMP21-22 genes on human chromosome 1p36.3 and their linkage to D1Z2. Genome Res. $\underline{8}$ (1998) 929-939.

24. Shi, J. and Nelson, M.A. The cyclin-dependent kinase 11 interacts with NOT2. Biochem. Biophys. Res. Commun. 334 (2005) 1310-1316.

25. Loyer, P., Trembley, J.H., Katona, R., Kidd, V.J. and Lahti, J.M. Role of CDK/cyclin complexes in transcription and RNA splicing. Cell. Signal. 17 (2005) 1033-1051.

26. Yokoyama, H., Gruss, O.J., Rybina, S., Caudron, M., Schelder, M., Wilm, M., Mattaj, I.W. and Karsenti, E. Cdk11 is a RanGTP-dependent microtubule stabilization factor that regulates spindle assembly rate. J. Cell Biol. 180 (2008) 867-875.

27. Petretti, C., Savoian, M., Montembault, E., Glover, D.M., Prigent, C. and Giet, R. The PITSLRE/CDK11p58 protein kinase promotes centrosome maturation and bipolar spindle formation. EMBO Rep. 7 (2006) 418-424.

28. Lahti, J.M., Xiang, J., Heath, L.S., Campana, D. and Kidd, V.J. PITSLRE protein kinase activity is associated with apoptosis. Mol. Cell. Biol. $\underline{15}$ (1995) 1-11.

29. Hu, D., Valentine, M., Kidd, V.J. and Lahti, J.M. CDK11(p58) is required for the maintenance of sister chromatid cohesion. J. Cell Sci. 120 (2007) 2424-2434.

30. Bunnell, B.A., Heath, L.S., Adams, D.E., Lahti, J.M. and Kidd, V.J. Increased expression of a $58-\mathrm{kDa}$ protein kinase leads to changes in the CHO cell cycle. Proc. Natl. Acad. Sci. U. S. A. 87 (1990) 7467-7471.

31. Zong, H., Chi, Y., Wang, Y., Yang, Y., Zhang, L., Chen, H., Jiang, J., Li, Z., Hong, Y., Wang, H., Yun, X. and Gu, J. Cyclin D3/CDK11p58 complex is involved in the repression of androgen receptor. Mol. Cell. Biol. 27 (2007) 7125-7142.

32. Hu, D., Mayeda, A., Trembley, J.H., Lahti, J.M. and Kidd, V.J. CDK11 complexes promote pre-mRNA splicing. J. Biol. Chem. 278 (2003) 8623-8629.

33. Chen, H.H., Wang, Y.C. and Fann, M.J. Identification and characterization of the CDK12/cyclin L1 complex involved in alternative splicing regulation. Mol. Cell. Biol. 26 (2006) 2736-2745.

34. Trembley, J.H., Hu, D., Hsu, L.C., Yeung, C.Y., Slaughter, C., Lahti, J.M. and Kidd, V.J. PITSLRE p110 protein kinases associate with transcription complexes and affect their activity. J. Biol. Chem. 277 (2002) 2589-2596.

35. Wendt, K.S., Yoshida, K., Itoh, T., Bando, M., Koch, B., Schirghuber, E., Tsutsumi, S., Nagae, G., Ishihara, K., Mishiro, T., Yahata, K., Imamoto, F., 
Aburatani, H., Nakao, M., Imamoto, N., Maeshima, K., Shirahige, K. and Peters, J.M. Cohesin mediates transcriptional insulation by CCCTC-binding factor. Nature $\underline{451}$ (2008) 796-801.

36. Spremo-Potparevic, B., Zivkovic, L., Djelic, N. and Bajic, V. Analysis of premature centromere division (PCD) of the $\mathrm{X}$ chromosome in Alzheimer patients through the cell cycle. Exp. Gerontol. 39 (2004) 849-854.

37. Zivkovic, L., Spremo-Potparevic, B., Djelic, N. and Bajic, V. Analysis of premature centromere division (PCD) of the chromosome 18 in peripheral blood lymphocytes in Alzheimer disease patients. Mech. Ageing Dev. 127 (2006) 892-896.

38. Bajic, V.P., Spremo-Potparevic, B., Zivkovic, L., Djelic, N. and Smith, M.A. Is the time dimension of the cell cycle re-entry in AD regulated by centromere cohesion dynamics? Biosci. Hypotheses 1 (2008) 156-161.

39. Migliore, L., Testa, A., Scarpato, R., Pavese, N., Petrozzi, L. and Bonuccelli, U. Spontaneous and induced aneuploidy in peripheral blood lymphocytes of patients with Alzheimer's disease. Hum. Genet. 101 (1997) 299-305.

40. Sternberger, L.A. Immunocytochemistry, Wiley, New York, 1986.

41. Wang, X., Su, B., Siedlak, S.L., Moreira, P.I., Fujioka, H., Wang, Y., Casadesus, G. and Zhu, X. Amyloid-beta overproduction causes abnormal mitochondrial dynamics via differential modulation of mitochondrial fission/fusion proteins. Proc. Natl. Acad. Sci. U. S. A. 105 (2008) 19318-19323.

42. Su, B., Wang, X., Drew, K.L., Perry, G., Smith, M.A. and Zhu, X. Physiological regulation of tau phosphorylation during hibernation. J. Neurochem. 105 (2008) 2098-2108.

43. Wang, X., Su, B., Fujioka, H. and Zhu, X. Dynamin-like protein 1 reduction underlies mitochondrial morphology and distribution abnormalities in fibroblasts from sporadic Alzheimer's disease patients. Am. J. Pathol. 173 (2008) 470-482.

44. Zhu, X., McShea, A., Harris, P.L., Raina, A.K., Castellani, R.J., Funk, J.O., Shah, S., Atwood, C., Bowen, R., Bowser, R., Morelli, L., Perry, G. and Smith, M.A. Elevated expression of a regulator of the G2/M phase of the cell cycle, neuronal CIP-1-associated regulator of cyclin B, in Alzheimer's disease. J. Neurosci. Res. 75 (2004) 698-703.

45. Harris, P.L., Zhu, X., Pamies, C., Rottkamp, C.A., Ghanbari, H.A., McShea, A., Feng, Y., Ferris, D.K. and Smith, M.A. Neuronal polo-like kinase in Alzheimer disease indicates cell cycle changes. Neurobiol. Aging 21 (2000) 837-841.

46. Previll, L.A., Crosby, M.E., Castellani, R.J., Bowser, R., Perry, G., Smith, M.A. and Zhu, X. Increased expression of p130 in Alzheimer disease. Neurochem. Res. $\underline{32}$ (2007) 639-644.

47. Ogawa, O., Zhu, X., Lee, H.G., Raina, A., Obrenovich, M.E., Bowser, R., Ghanbari, H.A., Castellani, R.J., Perry, G. and Smith, M.A. Ectopic localization of phosphorylated histone $\mathrm{H} 3$ in Alzheimer's disease: a mitotic catastrophe? Acta Neuropathol. (Berl). 105 (2003) 524-528. 
48. Bonda, D.J., Bajic, V.P., Spremo-Potparevic, B., Casadesus, G., Zhu, X., Smith, M.A. and Lee, H.G. Cell Cycle Aberrations and Neurodegeneration: A Review. Neuropathol. Appl. Neurobiol. $\underline{36}$ (2010) 157-163.

49. Zhu, X., Raina, A.K., Lee, H.G., Chao, M., Nunomura, A., Tabaton, M., Petersen, R.B., Perry, G. and Smith, M.A. Oxidative stress and neuronal adaptation in Alzheimer disease: the role of SAPK pathways. Antioxid. Redox Signal. $\underline{5}$ (2003) 571-576.

50. Mosch, B., Morawski, M., Mittag, A., Lenz, D., Tarnok, A. and Arendt, T. Aneuploidy and DNA replication in the normal human brain and Alzheimer's disease. J. Neurosci. 27 (2007) 6859-6867.

51. Yang, Y., Geldmacher, D.S. and Herrup, K. DNA replication precedes neuronal cell death in Alzheimer's disease. J. Neurosci. 21 (2001) 2661-2668.

52. Zhu, X., Siedlak, S.L., Wang, Y., Perry, G., Castellani, R.J., Cohen, M.L. and Smith, M.A. Neuronal binucleation in Alzheimer disease hippocampus. Neuropathol. Appl. Neurobiol. 34 (2008) 457-465.

53. Spremo-Potparevic, B., Zivkovic, L., Djelic, N., Plecas-Solarovic, B., Smith, M.A. and Bajic, V. Premature centromere division of the X chromosome in neurons in Alzheimer's disease. J. Neurochem. 106 (2008) 2218-2223.

54. Cash, A.D., Aliev, G., Siedlak, S.L., Nunomura, A., Fujioka, H., Zhu, X., Raina, A.K., Vinters, H.V., Tabaton, M., Johnson, A.B., Paula-Barbosa, M., Avila, J., Jones, P.K., Castellani, R.J., Smith, M.A. and Perry, G. Microtubule reduction in Alzheimer's disease and aging is independent of tau filament formation. Am. J. Pathol. 162 (2003) 1623-1627.

55. Lee, H.G., Ueda, M., Miyamoto, Y., Yoneda, Y., Perry, G., Smith, M.A. and Zhu, X. Aberrant localization of importin alphal in hippocampal neurons in Alzheimer disease. Brain Res. 1124 (2006) 1-4. 